\title{
OPEN DAYS PERIOD AND ANTISPERMATOZOAL ANTIBODIES IN ARTIFICIALLY INSEMINATED COWS
}

\author{
MILOVANOVIĆ $A^{*}$, LAZAREVIĆ $M^{* *}$, MILANOVIĆ SVETLANA**, KIROVSKI DANIJELA** \\ and JOVIČIN M* \\ * Scientific Veterinary Institute, Novi Sad \\ ** Faculty of Veterinary Medicine, Belgrade \\ (Received 2. May 2005)
}

The aim of this study was to determine titers of antisperm antibodies (ASA) of Ig G and Ig A class in sera and cervical mucus of artificially inseminated Holstein cows in order to correlate these results with the duration of the open days period. Investigations were conducted on a total of 181 cows originating from three different dairy farms. Blood and cervical mucus samples for laboratory analyses were collected on the day of the last artificial insemination. Presence of ASA was determined by indirect immunofluorescence method (IIF) using bulls' sperm cells prepared for artificial insemination by suspending in TRIS - egg yolk or "Biociphos +" extenders prior to deep freezing.

Our results strongly confirm the hypothesis that immune mechanisms may be involved in reproductive disturbances due to high levels of ASA of Ig A class. In the sera and cervical mucus of cows, high levels of ASA were found in animals with longer open days period. In this study we were not able to demonstrate differences in ASA titers when sperm cells were suspended in different extenders and used for the IIF test.

Key words: sperm cells, cows, artificial insemination, subfertility, antisperm antibodies

\section{INTRODUCTION}

Despite numerous clinical studies and experimental efforts, over the past four decades, the precise role and significance of antisperm antibodies (ASA) in the pathogenesis of immunological sterility and subfertility of both males and females still remains unclear. There are plenty of data accumulated, so far, and now it is evident that ASA may impair fertility to certain extent. The reasons for our inability to explain immunological subfertility lies in the fact that the mechanisms involved in the gamete immune protection are very complex and the immune response to their antigens is never an "all or none" phenomenon. This mechanisms are in details rewieved elsewhere (Hogarth, 1982 Bronson et al. 1998, Landers et al., 1994). Spermatozoa are foreign cells to males as they appear 
late into ontogenesis (in puberty), but their progenitors are separated from the immune cells by a blood-testis barrier during spermatogenesis (Furuya et al., 1978). Moreover, submucosa of the male reproductive tract is rich in $T_{s}$ cells and therefore, the immune response to spermatozoa is normally not elicited despite their isoantigenic properties (El Demiry and James, 1988). During passage through male and female genital tracts, spermatozoa are surrounded by seminal plasma that contains strong immunosuppressive molecules which block recognition and antigen processing (James and Hargreave 1984). Other molecules mask antigens important for the fertilization process on the surface of spermatozoa. In addition, cervical mucus, uterine and follicular fluid also contain immunosuppressive substances (Landers et al., 1994). One of the basic characteristics of sperm cells is a continuous change of their antigenic structure due to the loss of surface molecules during maturation and following insemination. Antisperm antibodies may be present in seminal plasma, cervical mucus (CM), uterine fluid, follicular fluid or blood sera (Stren et al., 1992). The role of ASA in infertility and subfertility in mammalian species is still not clearly understood but it is well known that auto-immunization of the male and isoimmunization of the female with sperm cells can lead to significant impairment of fertility. Experimentally generated bull antisperm antibodies significantly reduce fertilization in vitro (Kim et al. 1999). Much earlier, Wright (1980) described the negative influence of ASA, raised by intensive immunization, of adult animals on semen quality in the bull. This phenomenon has been recorded for numerous laboratory animals as reviewed by Hogarth (1982). Bratanov et al. (1980) showed that sera containing antisperm antibodies from infertile cows and women with unexplained infertility inhibit acrosomal proteolytic activity in vitro and therefore possibly may affect fertilization. Investigations in veterinary medicine regarding the influence of ASA in CM on fertility rates are very few. An elevation of spermagglutinating antibody titer in the $\mathrm{CM}$ and sera of artificially inseminated cows was clearly demonstrated by Jaćević (1998).

In the technology of artificial insemination (AI), the antigenic structure of sperm cells is changed due to the addition of different extenders, freezing and thawing procedures and reduction of seminal plasma volume. In addition, the immunosuppressive activity of bull seminal plasma is significantly reduced during semen preparation for Al (Lazarević, 1991). Therefore, we have investigated the presence of ASA in CM and sera using sperm cells previously suspended in two different extenders and correalted these findings with the duration of the open days period in artificially inseminated cows.

One of the most important reproductive parametars in cows is "open days period" being defined as a period between calving and the next successful insemination. Normal duration of open days period is essential in dairy cows breeding and our goal is usually to get one calf per year from each cow. This is not a simple task and on dairy farms repeat breeding (RB) still represents one of the major problems. A repeat-breeder is a cow which shows a reduced probability of conception, while all other factors are optimal (Casida, 1961), and thus requires more Al attempts to achieve pregnancy. These cows are subfertile and for that reaseon, unless they have a very high milk yeald, their presence in the herd 
elevates costs of milk production. If mated naturally, RB cows or heifers very often show improved reproductive results (Vukotić et al., 1982). It was postulated that enhanced immunological reactivity to sperm or semen extender antigens might be one of the reasons for RB (Park and Hunter, 1977). It has been documented (Lazarević et al,. 2003; Jaćević, 1998) by sperm agglutination and indirect immunofluorescence, that bull spermatozoa differ in antigenicity if different semen extenders are used for semen preparation for Al.

One of the major consequences of repeat breeding is a prolonged open days period and the aim of our study was to determine the levels of antisperm antibodies (ASA) of Ig G and Ig A class in the sera and cervical mucus of artificially inseminated Holstein cows and to correlate these results with the duration of the open days period.

\section{MATERIAL AND METHODS}

Sera sampling: Sera were collected from 181 Holstein cows at three regional dairy farms by jugular venipuncture on the day of artificial insemination. Sera were obtained following coagulation at room temperature and centrifugation at 3000 rpm for $20 \mathrm{~min}$. All samples were kept frozen at $-20^{\circ} \mathrm{C}$ until use. The animals were divided into two, three or five groups according to the average titer values for ASA of Ig G or Ig A class in the sera or cervical mucus. All cows were inseminated with bull semen prepared for AI with TRIS egg-yolk or "Biociphos +" extender.

Cervical mucus sampling: Prior to Al, CM samples were collected by placing a sterile sponge swab in the near vicinity of the external cervix portion. Sponges were placed with a sterile plastic tube $(1.5 \mathrm{~cm}$ width, $45 \mathrm{~cm}$ long) and the swab remained inside for the next 5 minutes. The swab was then removed and placed in an opened sterile syringe $(20 \mathrm{ccm})$. The syringe was closed and the cervical mucus extracted by gentle pushing into a sterile plastic polystyrene tube. We were able to collect approx. $3 \mathrm{ccm}$ of $\mathrm{CM}$. All samples were kept frozen at $-20^{\circ} \mathrm{C}$ until use.

Semen sampling: Semen samples were collected from four black and white spotted bulls (Holstein breed) by means of an artificial vagina in the Regional Centre for Artificial Insemination. All semen samples possessed normal characteristics of motility, morphology and concentration. Ejaculates were pooled and then divided into two equal portions (split technique). The ejaculates underwent the standard procedure of preparation for Al. One half of each ejaculate was diluted with TRIS - egg yolk extender as described elsewhere (Lazarević et al., 1992) and one with "Biociphos +" extender (IMV, France). Ejaculates were diluted at an average ratio of 1:10 and kept frozen at $-196{ }^{\circ} \mathrm{C}$ before use.

Indirect immunofluorescence assay (IIF): The IIF assay was performed according to Noel et al. (1974). After thawing the straws for Al (medium French straws $0.45 \mathrm{ml}$ ), sperm cells were separated and washed twice in PBS (pH 7.2) by centrifugation at $2000 \mathrm{rpm}$ for 10 minutes. We always used straws originating from 
the same four bulls ( 3 from each bull). When the last supernatant was discarded the remaining cells were resuspended by Vortex and used for smear preparations. On the microscope slides with dried sperm cell smears, $10 \mu \mathrm{l}$ of sera or CM sample (inactivated at $56^{\circ} \mathrm{C}$ for 20 minutes) was placed and incubated for $20 \mathrm{~min}$ at $37^{\circ} \mathrm{C}$ in a wet chamber. Sera and $\mathrm{CM}$ dilutions from 1:4 to $1: 1024$ (highest positive titer) were used for the test. Following incubation, the slides were washed three times (5 $\mathrm{min}$ ) in PBS and dried at room temperature. In the second step, 10 $\mathrm{ml}$ of secondary FITC (fluorescein isothiocyanate) conjugated antibody (anti bovine Ig A, ICN, USA, Cat No 641 751) was placed on the slide and incubated again under the same conditions. Anti Ig $A$ antibodies were conjugated with FITC (ICN, USA, Cat No F 4274) according to The and Feltkamp (1970). After incubation, followed by the same washing procedure, the slides were kept in a dark and wet chamber until examined. As a positive control we used sera obtained by immunization of calves with the content of straws prepared with TRIS - egg yolk extender and "Biociphos +" extender as described in detail elsewhere (Lazarevic et al., 2000). Two 5 month-old calves were immunized for the first time with the straw content mixed with complete Freunds adjuvant and for the second time (after two weeks) with straw content mixed with incomplete adjuvant. Calf sera before immunization served as the negative control. Microscopic examination was performed on the NIKON EFD - 3 microscope with the B-2A filter at $1600 \mathrm{X}$ magnification. The appearance of fluorescence on the head, tail or neck of the sperm cell was considered as a positive result and the last dilution giving a positive reaction was taken into account. Titre values were expressed according to Sjurin et al. (1984) as $-\log 2 \mathrm{n}(1: 2=1,1: 4=2$ etc).

Statistical analyses was performed after calculating mean values and standard deviations. The significance of the differences between mean values was estimated by Mann-Whitney test.

\section{RESULTS}

Figure 1. shows the correlation between titres of $\lg$ G ASA in the blood sera of cows and open days period. In this case we were not able to demonstrate statistically significant differences between groups of cows with different ASA levels.

The majority of animals had open days period between 150 - 200 days and no differences depending on the extender type were present. Similar results were obtained when titers of the $\lg$ G ASA were determined in the cervical mucus (Figure 2.).

When titers of the Ig A ASA in cows sera were correlated to the duration of the open days period, statistically significant differences were obtained between cows with the highest titers of ASA $(8.1>)$ and all other groups of animals. In this test we used sperm cells previously suspended in TRIS-egg yolk extender (Figure 3.). 
Acta Veterinaria (Beograd), Vol. 55. No. 5-6, 449-460, 2005.

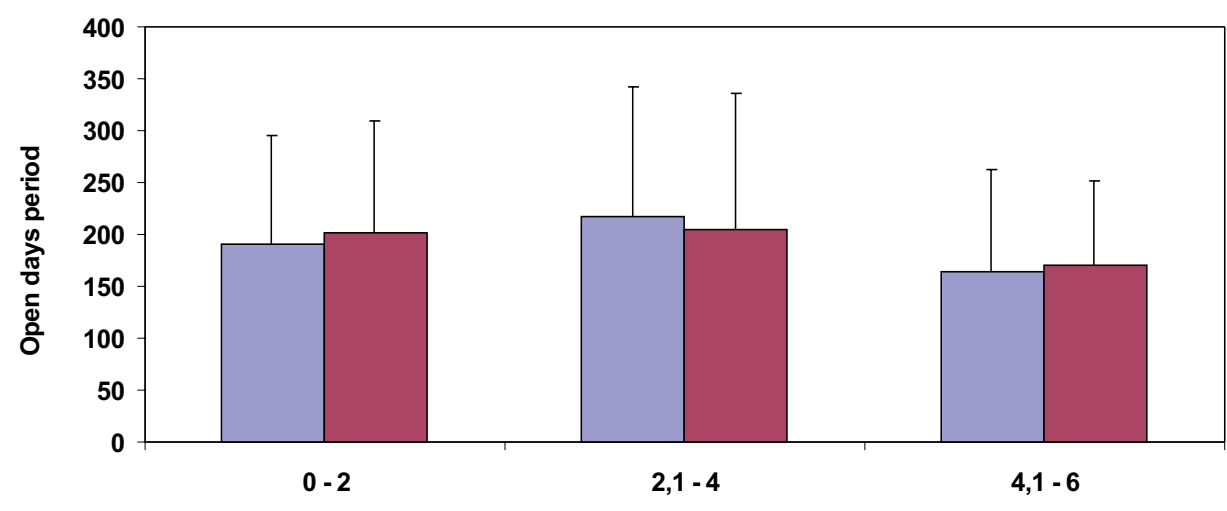

Titer of $\lg \mathbf{G}$ antibodies (- $\log _{2}$ ) in the blood sera of cows against spermatozoa suspended in TRIS egg yolk extender and "Biociphos +" extender

$\square \lg G$ - T $\square \lg G$ - B

Figure 1. Duration of the open days period according to the titre of the $\lg$ G ASA in the blood sera of cows against spermatozoa suspended in TRIS - egg yolk and "Biociphos +" extender

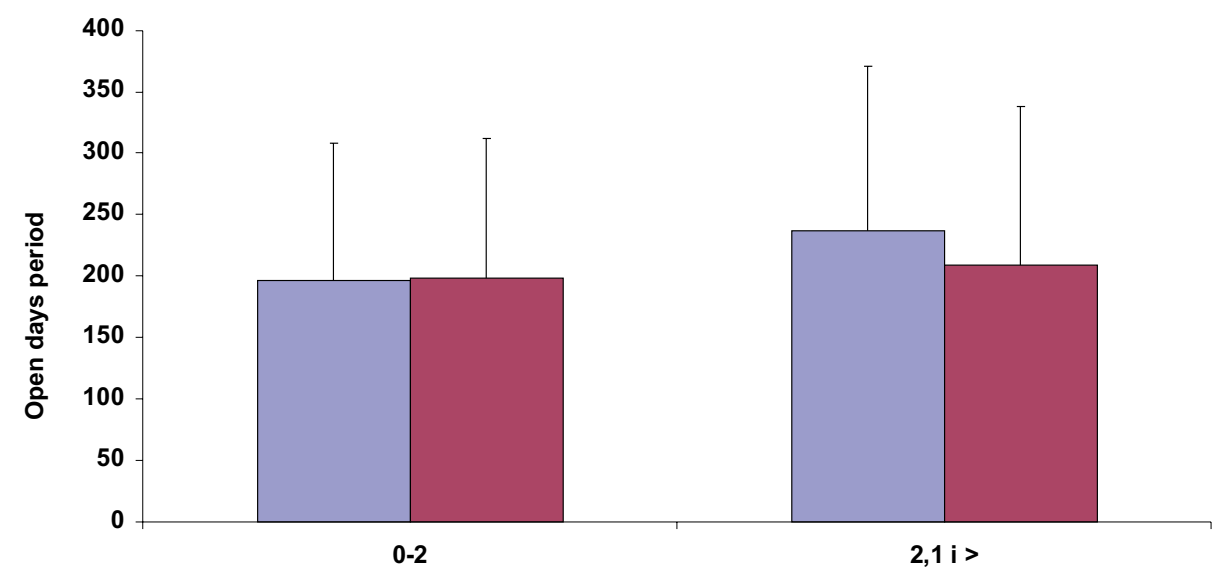

Titer of $\lg \mathbf{G}$ antibodies (- $\log _{2}$ ) in the cervical mucus of cows against spermatozoa suspended in TRIS egg yolk extender and "Biociphos +" extender

$\square \lg G$ - T $\square \lg G$ - B

Figure 2. Duration of the open days period according to the titer of the Ig G ASA in the cervical mucus of cows against spermatozoa suspended in TRIS - egg yolk and "Biociphos +" extender 


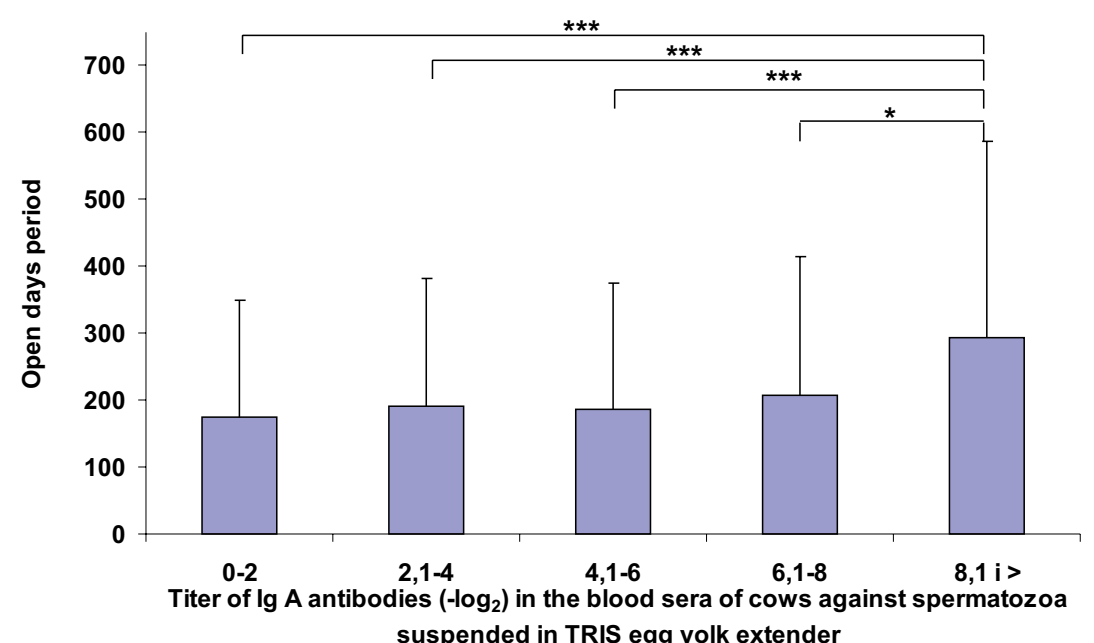

Figure 3. Duration of the open days period according to the titer of the $\lg$ A ASA in the blood sera of cows against spermatozoa suspended in TRIS - egg yolk extender

Figure 4. represents results of the tests performed with sperm cells suspended in TRIS-egg yolk extender in samples of cervical mucus.

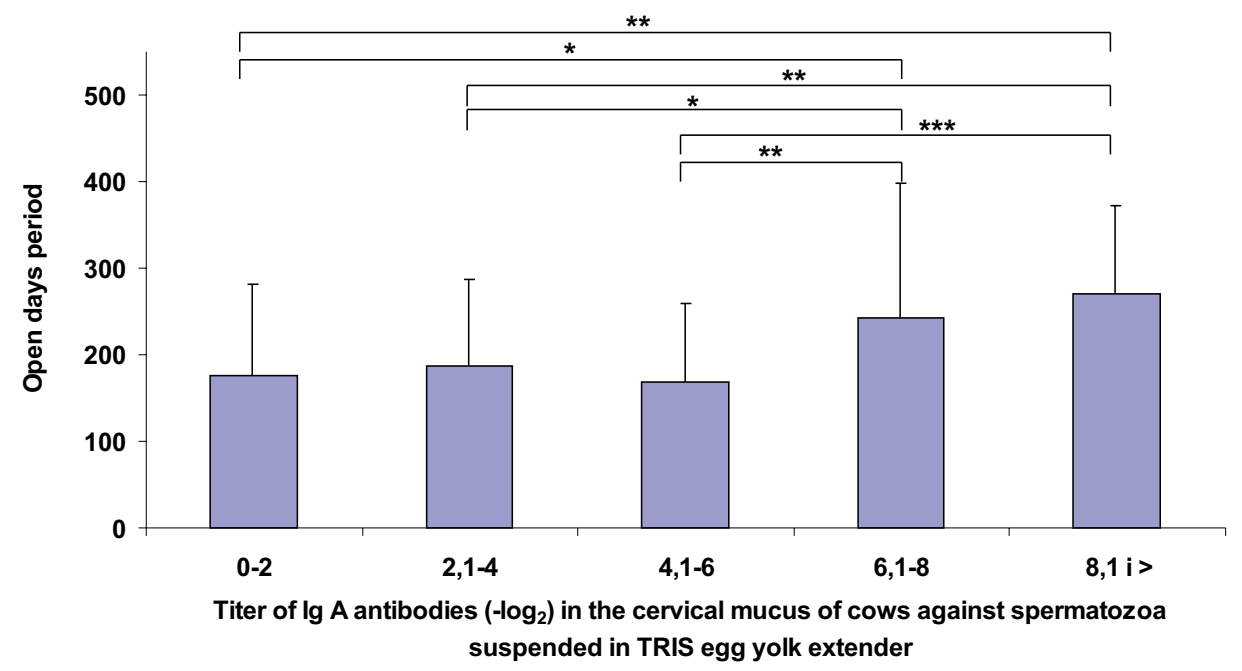

Figure 4. Duration of the open days period according to the titer of the $\lg$ A ASA in the cervical mucus of cows against spermatozoa suspended in TRIS - egg yolk extender 
As can be seen (Figure 4.) we were able to demonstrate statistically significant differences between nearly all groups and open days perod was prolonged in cows having higher titers of antisperm antibodies.

When sperm cells were suspended in "Biociphos + " extender we demonstrated the similar pattern comparing the duration of open days and titers of Ig A ASA (Figure 5.). In this case, cows with the highest Ig A ASA titer had slightly lower average values for the open days period and no stastistically significant differences were obtained between them and other groups of cows. However, statistically significant differences were documented between cows with ASA titers from $6.1-8$ and all other groups of animals.

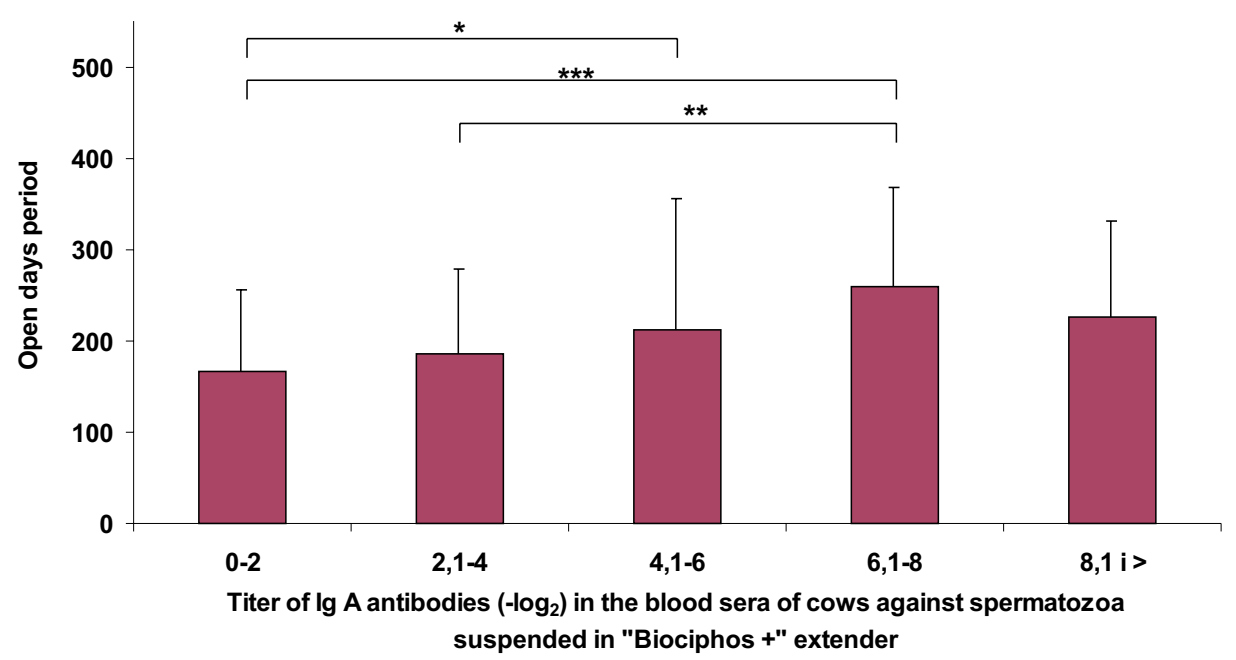

Figure 5. Duration of the open days period according to the titer of the Ig A ASA in the blood sera of cows against spermatozoa suspended in "Biociphos +" extender

Nearly same results were obtained in samples of cervical mucus when sperm cells also suspended in "Biociphos +". extender were used for IIF test (Figure 6).

We were, thus able, to conclude that titers of Ig G ASA in the sera and cervical mucus of cows did not correlate with the duration of the open days period. On the contrary, strong correlation was observed between titers of $\lg A$ ASA and open days period. No differences were related to the type of the extender used. 


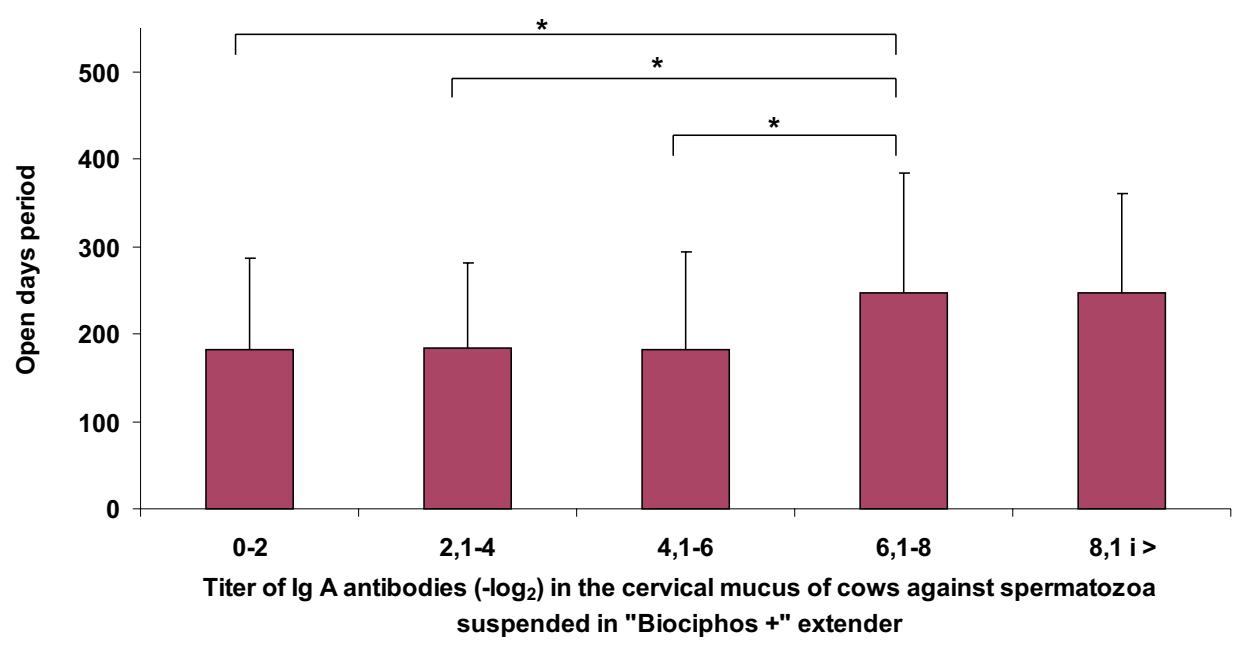

Figure 6: Duration of the open days period according to the titer of the Ig A ASA in the cervical mucus of cows against spermatozoa suspended in "Biociphos + "extender

\section{DISCUSSION}

Artificial insemination (Al) of cows is one of the useful models for studying ASA significance because in this case, natural conditions of insemination are significantly changed. This enables us to explore the role of certain mechanisms involved in the immunological protection of male gametes. Firstly, during preparation of semen for Al, seminal plasma is diluted several times thus reducing its immunosuppressive activities (Lazarević, 1991; Lazarević et al., 1992). Secondly, new antigens are being added to sperm suspension in order to replace seminal plasma and to provide cryoprotection. We have also documented that mean titers of the Ig A ASA are higher in the repeat breeder cows (Lazarević et al, 2003). For these reasons, possibilities for an immune response elicitation are higher in artificially inseminated cows and problems in reproduction are most prominent in cattle breeding.

Interference of ASA with reproductive processes may occur by impairment of sperm migration through the cervix, uterus and tubes and by blocking adherence of spermatozoa to the surface of the zona pellucida of the oocyte as postulated by Schumacher (1998). The same author stated that serum antibody levels do not reflect properly the immunological situation in secretions of the genital tract especially in females, and that the secretory immunological system may be operational mainly in the cervical compartment of the genital tract which is in agreement with our findings. Our results are also in agreement with Marshburn and Kutteh (1994), Mazumdar and Levine (1998) and Stern et al. (1992) who proved that $A S A$ in the blood and lymph belong predominantly to the 
immunoglobulin Ig $\mathrm{G}$ isotype, while those found in external secretions are predominantly of $\lg A$ isotype. It is also proved that circulating ASA of $\lg A$ and $\lg G$ classes recognises different antigens on the human sperm plasma membrane (Auer et al., 1997). In our investigations higher titers of Ig A ASA were detected both in sera and cervical mucus of cows. Nonspecific ASA are also demonstrable in heifers and prepubertal calf's sera but the titers are much lower (Lazarevic et al, 2003). In this study we were not able to demonstrate differånces in ASA levels, both in sera and cervical mucus, when sperm cells suspended in two different extenders were used for IIF test. This data are in desagreement with Jaćević (1998) but all cows included in her investigations were inseminated only with semen prepared for Al with TRIS - egg yolk extender which was not the case in our study.

Maas et al. (1998) demonstrated a close correlation between a positive sperm antibody test and a poor postcoital test in infertile couples. These authors concluded that determination of ASA in the CM must be regarded as an improvement in the diagnostic procedure in human infertility. We have also reviewed the possible negative influence of antisperm antibodies on reproduction processes (Jaćević and Lazarević, 2000). In one survey (Shulman, 1977) it was found that in a large group of infertile women who were seronegative, $28 \%$ were positive in their CM. In our study we were also able to demonstrate that some sera samples had no detectable antisperm antibodies (data not presented here).

There is strong evidence that in humans sperm-mucus interactions can be affected by local ASA, especially of the Ig A class, both under in vitro and in vivo conditions (Eggert-Kruse et al., 1991). However, the significance of ASA in sera of infertile patients was not established, while those in seminal plasma or CM impaired the ability of sperm cells to penetrate CM (Eggert-Kruse et al., 1995). Check et al. (1994) demonstrated that the antifertility effect of ASA may be mainly due to immobilization of sperm in the $\mathrm{CM}$ and thus intrauterine insemination may effectively correct the problem. The role of antisperm $\lg \mathrm{A}$ antibodies in man has also been documented by Clarke et al. (1984) and Kremer and Jager (1988). Recently, in veterinary medicine valuable data were obtained by analysing sera of 537 cows by ELISA test for ASA (Zraly et al., 2003). The authors were able to detect higher concentrations of ASA in pluriparus cows and also in cows that were inseminated repeatedly. Their results are also in agreement with our findings. Vukotić et al. (1982), showed that reactivity of female blood serum towards sperm cells increases with repeated Als and parallel to that, the probability of conception declines. This is also partly in agreement with our results. Presence of $\lg$ A ASA, especially in cervical mucus is of great significance because the attachment of Ig A antibodies to the sperm surface lowers sperm penetration ability, while $\lg G$ antibodies did not have the same effect. Wang et al. (1985). Moghissi et al. (1980) found antibody activity in the mucus of $26 \%$ in a group of infertile women and none in the control group. They detected such activity in serum in only $13 \%$ of infertile women. These findings are also in agreement with our results. Menge and Natz (1993) later demonstrated the presence of $\lg A 1$ and $\lg A 2$ subclasses in the CM of women. 
Our data regarding correlation between open days period and levels of ASA in the cervical mucus and sera are a new contribution to the problem of "repeat breeder cow". We hope that this approach may contribute in overcoming it.

\section{ACKNOWLEDGEMENT:}

This work was supported by a grant from the Ministry of Science, Technology and Development of the Republic of Serbia, No 1998, (Investigations of systemic and local immune reactivity of heifers and cows to sperm antigens and semen extenders).

Address for correspondence:

Prof. Dr Miodrag Lazarević

Faculty of Veterinary Medicine

Department of Physiology and Biochemistry

Bul JNA 18, Belgrade

Serbia \& Montenegro

e-mail: mishaŽvet.bg.ac.yu

\section{REFERENCES}

1. Auer J, Senechal H, De Almeida M, 1997, Sperm-associated and circulating Ig A and Ig G classes of antibodies recognise different antigens on the human sperm plasma membrane, $J$ Reprod Immunol, 34, 121-36.

2. Bratanov K, Tornyov A, Somlev B, 1980, Effect of antisperm sera on the acrosomal proteolytic activity in vitro, Int $J$ Fertil, 25, 275-80.

3. Casida EL, 1961, Present status of the repeat breeder cow problem, J Dairy Sci, 44, 2323-9

4. Check JH, Bollendorf A, Katsoff D, Kozak J, 1994, The frequency of antisperm antibodies in the cervical mucus of women with poor postcoital test and their effects on pregnancy rates, $A m \mathrm{~J}$ Reprod Immunol, 32,1 38-42.

5. Clarke GN, Stojanoff A, Cauchi MN, McBain JC, Speirs AL, Johnston WI, 1984, Detection of antispermatozoal antibodies of Ig A class in cervical mucus, Am J Reprod Immunol, 5, 2, 61-5.

6. El Demiry M, James K, 1988, Lymphocyte subsets and macrophages in the male genital tract in health and disease, Eur Urol, 14, 226-35.

7. Eggert Kruse W, Hofsass A, Haury E, Tilgen W, Gerhard I, Runnebaum B, 1991, Relationship between local anti-sperm antibodies and sperm-mucus interactions in vitro and in vivo, Hum Reprod, 6 , $2,267-76$

8. Eggert Kruse W, Rohr G, Bockem-Hellwig S, Huber K, Christmann-Edoga M, Runnebaum B, 1995, Immunological aspects of sub fertility, Int J Androl, 18, Suppl 2, 43-52.

9. Furuya S, Kamamoto Y, Sugiyama S, 1978, Fine structure and develpment of Sertoly junctions in human testis, Arch Androl, 1, 211 -9.

10. Hogarth JP, 1982, Immunological aspects of mammalian reproduction, Blackie, Glasgow \& London, 50-83.

11. James K, Hargreave TB, 1984, Immunosuppression by seminal plasma and its possible clinical significance, Immunol Today, 5, 357-63.

12. Jaćević V, 1998, Spermaglutinini u krvnom serumu i cervikalnoj sluzi junica i krava sa različitim indeksom osemenjavanja, Magistarska teza, Fakultet veterinarske medicine, Beograd.

13. Jaćević $V$, Lazarević $M, 2000$, Antitela protiv spermatozoida i njihov značaj u patogenezi neplodnosti žena, Vojnosanit Pregl, 57, 331-8.

14. Kim CA, Parrish JJ, Momont HW, Lunn DP, 1999, Effects of experimentally generated bull antisperm antibodies on in vitro fertilization, Biol Reprod, 60, 1285-91.

15. Kremer J, Jager SD, 1988, Sperm-cervical mucus interaction, in particular in the presence of antispermatozoal antibodies, Hum Reprod, 3,1, 69-73.

16. Landers DL, Bronson AD, Pavia SC, Stites PD, 1994, Reproductive immunology, In Stites PD, Terr IA, Parslow GT eds, Medical Immunology, Appletone and Lange, 200-15. 
Acta Veterinaria (Beograd), Vol. 55. No. 5-6, 449-460, 2005.

17. Lazarević M, 1991, Ispitivanje imunomodulatornih uloga semene plazme bika u in vitro uslovima, Doktorska disertacija, Fakultet veterinarske medicine, Beograd

18. Lazarević M, Ejdus L, Rosić G, 1992, The influence of bovine seminal plasma, egg yolk extender and their mixture on bovine lymphocyte blastogenesis, Acta veterinaria, 42, 4, 227-236.

19. Lazarević M, Kirovski D, Fratrić N, Milanović S, Jakovljević G, Milovanović A, 2002, The presence of naturally occurring antisperm antibodies in the sera of prepubertal calves, Acta veterinaria, 52,5-6, 311-9.

20. Lazarević M, Milanović S, Kirovski D, Milovanović A, 2003, Antisperm antibodies of the lg A class in the cervical mucus and sera of artificially inseminated cows, Acta veterinaria, 53,5-6, 311-20.

21. Maas DH, Timm G, Mesrogli M, Degenhardt F, 1989, Spermatozoal antibodies in cervical mucus and in the luminal fluid of the uterus in sterile patients, Geburtshilfe Frauenheilkd, 49, 3, 248-51.

22. Marshburn PB, Kutteh WH, 1994, The role of antisperm antibodies in infertility, Fertil Steril, 61, 64451.

23. Mayumdar S, Levine AS, 1998, Antisperm antibodies: etiology, pathogenesis, diagnosis and treatment, Fertil Steril, 70, 799-810.

24. Menge Ac, Naz RK, 1993, Immunoglobulin (lg) G, A and Ig A subclass antibodies against fertilization antigen 1 in cervical secretion and sera of women of infertile couples, Fertil Steril, 60,4, 658-63.

25. Moghissi KS, Sacco Ag, Borin K, 1980, Cervical mucus antibodies and postcoital test, Am J Obstet Gynecol, 136, 941-8.

26. Noel RR, Hjort T, Rumke P, Harper JKM, Vyazov O, 1974, Techniques for detection of iso- and autoantibodies to human spermatozoa, Clin Exp Immunol, 23, 175-99.

27. Park WY, Hunter GA, 1977, Effect of repeated inseminations with egg yolk semen extender on fertility in cattle, J Dairy Sci, 60, 1645-9.

28. Shulman S, 1977, Immune activities of the male and female reproductive tracts, In: Immunological Influence on Human Fertility (Ed B. Boetther), Academic Press, Sydney, 87-102.

29. Schumacher GF, 1988, Immunology of spermatozoa and cervical mucus, Hum Reprod, 3,3, 289300.

30. Sjurin N, Belorusova VR, Fomina VM, 1984, Veterinarnaja virusologija, Kolos, Moskva.

31. Stern JE, Dixon PM, Manganeillo PD, Brinck-Johnsen T, 1992, Anti-sperm antibodies in women: variability in antibody levels in serum, mucus and peritoneal fluid, Fertil Steril, 60,1 -6.

32. The TH, Feltkamp TWE, 1970, Conjugation of fluorescein isothiocyanate to antibodies, I Experiments on the conditions of conjugation, Immunol, 18, 868-73.

33. Vukotić M, Pavlović M, Stojić V, Petrović S, Kuzmanov D, Predojević M, 1982, Some evidence on immunological resistance of heifers to artificial insemination, In: Proc 4th Int Symp Immunol Reprod, Varna, P 125.

34. Wang CH, Baker HW, Jennings MG, Burger H, Lutjen P, 1985, Interaction between human cervical mucus and sperm surface antibodies, Fertil Steril, 44,4, 484-8.

35. Zraly Z, Canderle J, Dibikova I, Švecova D, Mašova J, Kummer V, 2003, Antisperm antibodies in cows related to their reproductive health, Acta Vet Brno, 72, 27-32. 


\section{SERVIS PERIOD I ANTITELA PROTIV SPERMATOZOIDA KOD VEŠTAČKI OSEMENJAVANIH KRAVA}

\section{MILOVANOVIĆ A, LAZAREVIĆ M, MILANOVIĆ SVETLANA, KIROVSKI DANIJELA i JOVIČIN M}

U ovom radu su izneti rezultati ispitivanja titra antitela $\lg \mathrm{G}$ i lg A klase poreklom iz krvnog seruma i cervikalne sluzi veštački osemenjavanih holštajn krava protiv antigena spermatozoida bika. Ispitivanja su izvedena na ukupnom broju od 181 plotkinje sa tri regionalne farme muznih krava. Uzorci krvi i cervikalne sluzi su prikupljeni na dan poslednjeg veštačkog osemenjavanja. Titar antitela protiv antigena spermatozoida (ASA) je određivan metodom indirektne imunofluorescence a za izvođenje testa su korišćeni spermatozoidi suspendovani u TRIS žumanjčanom ili "Biociphos + " razređivaču.

Naši rezultati potvrđuju hipotezu da su imunski mehanizmi uključeni u nastanak nekih reproduktivnih poremećaja jer su plotkinje sa visokim titrom ASA u serumu i cervikalnoj sluzi imala duži servis period. Osim toga, u ovim ispitivanjima nismo utvrdili postojanje razlika u titru ASA u zavisnosti od vrste korišćenog razređivača. 